\title{
Harran Ovası sulamasında tekrar kullanılan drenaj sularının kullanımı ve kalitesi*
}

\author{
Ali Riza ÖZTÜRKMEN1, İlknur SÜPÜRKECI YARMAÇ²
}

${ }^{1}$ Harran Üniversitesi Ziraat Fakültesi Toprak bilimi ve Bitki Besleme Bölümü, ŞANLIURFA

²DSi 15. Bölge Müdürlüğü, ŞANLIURFA

*HÜBAK tarafindan 15049 nolu projeyle desteklenmiştir.

Alınıș tarihi: 8 Haziran 2018, Kabul tarihi: 4 Eylül 2018

Sorumlu yazar: Ali Riza ÖZTÜRKMEN, e-posta:arozturkmen@harran.edu.tr

\section{$\ddot{0} \mathbf{z}$}

Gelecekte artan nüfus ile su tüketiminin artacağı bilinmektedir. Ülkemizde suyun en fazla tarımda kullanıldığı için tarımsal sulama önemlidir. Sulama bitkisel üretimi sınırlayan en önemli faktörlerdendir. Sulanabilir arazi alanının artmasıyla tarımsal su ihtiyacı artmaktadır. Bu yüzden artan su ihtiyacının karşılanması için su tasarrufu yoluna gidilmeli ve kaliteli drenaj sularının tekrar kullanılmalıdır. Drenaj sularının içeriğindeki kirleticilerin miktarı düşünüldüğünde, kalitesinin iyileștirilerek yeniden kullanılması ve kullanım süresince takip edilerek kullanılması gerekmektedir. GAP projesi kapsamında 1995 yılında başlatılan sulama, kademeli olarak arttırarak 147.887 hektarlık alanda yapılmaktadır. Harran Ovasının sulamasında, suyun, ovanın sonuna ulaşmaması nedeniyle, yer altı kuyuları açılmış ve drenajdan elde edilen geri dönüșüm suları regülatör yardımıyla sulama suyuna karıştırılarak tekrar kullanılmaya başlanmıştır. Harran Ovasında drenaj kanalındaki sular ile sulama yapmak yaygınlaştırılmıştır. Bu hem sulama etkinliğini arttırmış, hem de ova dışına drenajla akıp giden su miktarını azaltmıştır. Bu çalışmada, sulamada kullanılan geri dönüşüm sularından örnekler alınarak, EC (Elektriksel iletkenlik), pH ve SAR (Sodyum adsorbsiyon oranı) analizleri yapılmıştır. Analiz sonuçlarına göre, kış aylarında toplanan su örneklerinin EC değerleri yaz aylarından toplanan örneklerin EC değerlerinden daha yüksek olduğu bulunmuş ve sonuç olarak bu suların sulamada değerlendirilebileceği kanısına varılmıştır.

Anahtar kelimeler: Tahliye suyu, Harran Ovası, sulama
The use and quality of reused drainage waters in Harran Plain irrigation

\section{Abstract}

It is known that water consumption will increase with increasing population in future. Agricultural irrigation is important because water is the most used in agriculture in our country. Irrigation is the most important factor limiting crop production. Increasing the area of irrigable land increases the need for agricultural water. Therefore, in order to meet the increasing water need, water saving should be done and quality drainage water should be reused again. When the amount of pollutants contained in drainage waters is considered, quality should be improved and reused and followed up during use. The irrigation started in 1995 within the scope of the GAP project is gradually increasing to 147,887 hectares of area. Because the water did not reach the end of the plain, the underground wells were opened and the recycling water obtained from the drainage was mixed with the irrigation water with the help of regulator and started to be reused again. Watering with drainage canals is common in Harran plains. This has increased both irrigation efficiency and reduced the amount of water flowing out of the plain by drainage. In this study, EC (electrical conductivity), $\mathrm{pH}$ and SAR (sodium adsorption ratio) analyzes were carried out by taking samples from the recycled water used in the irrigation. According to the results of the analysis, EC values of water samples collected during winter months were found to be higher than EC values of samples collected from summer months, and as a result, it was concluded 
that these water samples could be evaluated in water.

Key words: Discharge water, Harran Plain, irrigation

\section{Giriş}

Artan nüfus ve su tüketiminin artması nedeniyle ilerleyen zamanlarda büyük su sorunlarının oluşacağl tahmin edilmektedir. Bu nedenle su tasarrufu sağlayacak her türlü önlemin alınması gerekmektedir. Bilindiği üzere bitkisel üretimi sınırlayan en önemli faktörlerden biride sulamadır. Sulanabilir arazi sayısının zaman içinde sürekli artması nedeni ile tarımsal su ihtiyacı artmaktadır. Bu nedenle oluşacak su sıkıntısı sorunlarının çözümü için su tasarrufu yoluna gidilmeli ve sulamadan dönen veya evsel atık sularının tekrar kullanımı ile ilgili çalışmalar yapılmalıdır. Son 20 yıl içerisinde, dünyanın kurak bölgelerinin birçoğunda sulama suyu gereksiniminin \%70-90’ının geri kazanılmış sulardan sağlandığı belirtilmiştir (Gökçay, 2008).

Uzun vadede sulama, özellikle drenajı kötü topraklarda tuzluluğa ve ağır metal birikimine neden olabileceğinden, atık su sulaması yapılacak alanlarda periyodik toprak analizleri yapılarak, toprakta olası olumsuz değișimlerin gözlenmesi sağlanmalıdır (Büyükkamacı, 2008). Sulamadan dönen tahliye ve drenaj sularının içeriğindeki kirleticilerin miktarı düşünüldüğünde, drenaj sularının kalitesinin iyileştirilerek yeniden kullanılması ve kullanım süresince kalite değerleri takip edilerek kullanılması gerekmektedir.

Alcamo ve ark. (2007), tarafından yapılan çalışmada 2070 yılında su tüketimi tahmin edilmiş olup, çalışmalarında su tüketiminin 2070 yılında en fazla olacağı ülkenin Türkiye olduğunu tahmin etmişlerdir. Çiftçi ve ark. (1995), Konya Bölgesinde yaptıkları bir araştırmada sulu tarım yapılan alanlarda çiftçilerin yaklaşık \%22'sinin sulamada tarladan dönen suların kullandığını belirtmişlerdir. Apan (1992), Bafra Ovasında yaptıkları bir çalışmada sulama şebekesi inşaatının bitmemiş olduğu alanlarda ve sulama sahası dışında kalan alanlarda sulama suyu olarak yer altı suyu veya sulamadan dönen suların kullanılmakta olduğunu belirtilmektedir. Yurtseven (1993), yaptığı bir çalışmada, tahliye ve drenaj sularının sulama amacıyla tekrar kullanılması belli nedenlerden kaynaklandığını bunların; tahliye veya drenaj suyunun deşarj edileceği çıkış ağzının olmaması, sulama yapılan bölgede sulama suyunun yetersiz olması veya tahliye edilen su hacminin azaltılmak istenmesi ola- bileceğini belirtmiştir. Çullu (2008)'e göre Şanlıurfa Harran Ovaları sulaması kapsamında ovaya verilen suyun yaklaşık 1/3'ünün taban suyuna eklendiği ve yüzeysel akışa geçerek, ovadan atıldığı belirtilmiştir.

Aşık ve ark. (1997), Atık suların alternatif su kaynaklarının başında arıtılmış suların geldiği belirtilmektedir. Bu nedenle tahliye sularının su tüketimin fazla olduğu sektörlerden biri olan tarımda kullanılması üzerine çeşitli araştırmalar yapılmıştır. Weber ve ark. (1996) ve Kızlloglu (2008), atık suların sulamada kullanılması durumunda içeriğinde yer alan besin maddeleri ve organik madde ile verimli bir su kaynağı olduğunu ancak bu olumlu yanının dişında içeriğinde yer alabilecek olan ağır metal, zehir vb. zararlı maddeleri de barındırabileceği için büyük çevresel sorunlara yol açabilir demektedirler. Bu nedenle uygun arıtma sistemlerinden geçildikten sonra kalitesi değerlendirilerek tarımda kullanılması uygundur. Doğan (2003), Harran Ovasında yaptığı bir çalışmada, atık sularının deşarj edildiği Karakoyun Deresinden alınan su ile yapılan soğan bitkisi üzerindeki yapılan araştırma sonucunda; kullanılan su üzerinde yapılan analizlerde $\mathrm{As}, \mathrm{Cu}$ ve $\mathrm{Cd}$ miktarlarının sulama suyu kalite sınır değerlerinin üzerinde olduğunu belirtmişlerdir. Bu nedenle sulamada kullanılması muhtemel su kaynakları üzerinde çevresel sorunlara yol açılmaması için su analizlerinin yapılması gerektiği vurgulanmıştır. İşcan ve ark. (2001), yılında yaptıkları çalışmada, Güneydoğu Anadolu Bölgesinde sulamaya açllan alanların artmakta olduğunu bu nedenle sulama suyuna duyulan ihtiyacında arttığını belirtmişlerdir. Ovada sulamada kullanılacak olan kullanılabilir yeterli ve iyi nitelikli su bulunamaması durumunda, düşük kaliteli tuzlu sular ve hatta sulamadan dönen sular değerlendirilmektedir. Böyle durumlarda kullanılacak suyun sulamada kullanılmasının uygun olup olmadığı değerlendirilmeden yapılan sulamalar nedeniyle, toprağın fiziksel ve kimyasal özellikleri olumsuz yönde etkilenmekte, verim düşmekte ve çevresel sorunlara yol açmakta olduğunu belirtmiştir. Berekatoğlu ve ark. (2005), yılında Harran Ovasında ki sulamadan dönen suların tekrar sulamada kullanılabilmesi amacıyla yapılan araştırmada; sulama sularına ait değerler incelendiğinde genellikle temmuz ve ağustos aylarında elektriksel iletkenlik değerinin azaldığını, üç yıllık takip sonucunda ise tahliye suları ile sulanan toprak örneklerinde tuzluluk seviyesinde önemli bir değişikliğe rastlamamışlardır. Dizdar (2003), ise yaptığı çalışmada Şanlıurfa ilinde yaşanan tuzluluk sorunun sebebinin ise bilinçsiz yapılan sulamalar sonucu 
meydana geldiğini ve bunun nedenin ise, "Şanlıurfa'daki Harran ve Suruç Ovalarında toprağın altında tuzun bulunmasıdır. Yeterli drenaj önlemleri alınmazsa, sulama arttıkça bu tuzlar yüzeye doğru yükselecektir" demektedir. Çiftçi ve ark. (1995), Konya Ovasında yaptıkları çalışmada tahliye suyu ile sulanan alanlardan ve kuru tarım yapılan arazilerden alınan toprak örneklerinde sulanan alanlardaki tuzluluk seviyesinin sulanmayan alanlardaki tarım arazilerine göre daha fazla sorun oluşturacağını tespit etmişlerdir. Bunun sebebinin ise toprak içeriğinde bulunan tuzun sulama nedeniyle yüksek sıcaklıklarda kapilarite ile aktif hale geçebileceğini tespit etmişlerdir. Çullu ve ark. (2000), Harran Ovası topraklarında sulamanın topraklardaki fiziksel ve kimyasal özellikleri üzerindeki değișimi incelemişlerdir. İnceleme sonucuna göre sulama ile agregasyon ve strüktür stabilitesinde azalma olduğu görülmüș olup, sulamanın hidrolik iletkenlik ve kil minerali içeriğinde etkisi olmadığı, ancak sulama ile toprak tuzluluğunda bir artış olduğunu tespit etmişlerdir. Hidrolik iletkenlik ve kil minerali içeriğinde önemli bir fark olmamasının sebebinin toprağın fiziksel bir bozulum eğiliminde olmadığı ancak ilerleyen yoğun sulama dönemlerinde hidrolik iletkenlik ve kil minerali değerlerinin de olumsuz yönde etkilenmesi olasıdır Sulama ile agregasyon ve strüktür stabilitesinde tespit edilen azalmanın ise yıkanma ile toprak agregat yapısının bozulduğunu ve yanlış sürüm teknikleri ve münavebe yapılmaması nedeniyle strüktür stabilitesinde azalma olduğu tahmin edilmektedir. Tarboton ve ark. (2004), sulama yönetim teknikleri üzerine yapılan bir araştırmada, sulama sezonunca yapılan taban suyu ölçüm sonuçlarında, taban sularının kalitesi de incelenmiş olup, sulama suyu kalitesinin genellikle sulamadan dönen sular ile sulanan alanlar da düşük olduğu tespit edilmiştir. Çullu ve ark. (2000), tarafından yapılan bir çalışmada, Harran ovasındaki smektit kil mineralince baskın toprakların strüktürel özellikleri ve tuzlulaşma değerleri araştırılmıştır. Çalışmada, yüksek oranda bulunan değişebilir sodyumun önemli yapı bozulmalarına neden olduğu aynı zamanda strüktür ve agregat stabilitesini olumsuz yönde etkilediğini belirtmişlerdir. Çalışmanın sonucunda, toprak derinliğinin arttığı yerlerde elektriksel iletkenlik ve değişebilir sodyum oranının (ESP) arttığı, ancak değișebilir sodyum oranı artması ile hidrolik iletkenlik değerinin azaldığını belirtmişlerdir.

\section{Materyal ve Yöntem Materyal}

Araştırmada materyal olarak, Ovada bulunan 3 adet regülatör ve 1 adet tahliye kanalından alınan su örneklerinin ylllık Elektriksel İletkenlik (EC) değerleri ve Haziran ayında yapılan örneklemede pH, EC ve SAR oranı hesapları yapılmıştır. Çalışma alanı, su (S1, S2, S3, S4) örneklerinin alındığı yerler Şekil 1'de görülmektedir.

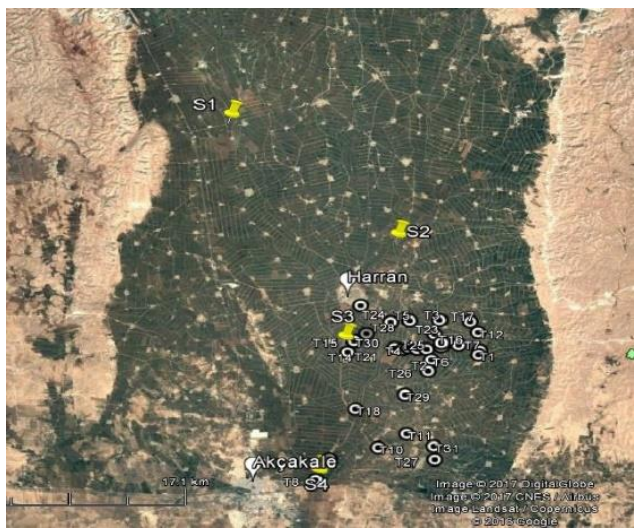

Şekil 1. Su örneklerinin alındığı yerler

\section{Alanın iklim özellikleri}

Genel olarak, çalışma sahası sıcak yaz ve serin-nemli kış ayları dolayısıyla tipik bir kurak ve yarı kurak iklim özelliği gösterir. Harran Ovası karasal ikliminin özelliklerini taşımakla beraber Akdeniz ikliminin tesiri de vardır. Uzun yıllar iklim verilerine göre Harran Ovasında yıllık ortalama yağış $451 \mathrm{~kg} / \mathrm{m}^{2}$ $\mathrm{mm}$, yıllık ortalama sıcaklık $18.3^{\circ} \mathrm{C}$ ve yıllık buharlaşma 1849 mm'dir (Anonim, 2017). Yağış̧ı büyük bir kısmı kış ve ilkbahar mevsimlerinde gerçekleşir. Özellikle Haziran ve Eylül ayları arası neredeyse tamamen yağışsız bir dönem özelliği gösterir. Kış aylarında da yetersiz yağış alan ova toprakları, aynı zamanda uzun bir süre yüksek sıcaklığın etkisi altında olup, Mayıs ile Kasım ayları arasında çok az miktarda yağış almaktadır. Toprak yüzeyinden meydana gelen buharlaşma oransal olarak neredeyse yağışın dört katı seviyesindedir. En yüksek buharlașma Temmuz ayında ve en düșük buharlașma ise Ocak ayında oluşmaktadır. Bu değerler ovada tarımsal faaliyetler için kontrollü sulamanın önemini göstermektedir (Çullu M.A., 2010). Ovada yaz aylarında şiddetli yüksek sıcaklıklar ve bu nedenle buharlaşmanın da fazla olması nedeniyle tarım topraklarının tuzlanması hızlanmaktadır. Yüksek sıcaklıklar topraktaki kapillariteyi şiddetlendirdiği için topraktaki tuzlanma artış göstermektedir. İnceleme alanında Mayıs ayından Ekim ayına kadar yaklaşık altı ay süresince yağıș hemen hemen hiç düşmemekte ve bu 
dönemde yüksek sıcaklıklardan dolayı șiddetli buharlaşmalar görülmektedir. Yaz aylarındaki yüksek sıcaklıklardan dolayı gerçekleşen buharlaşmalar toprak yüzeylerinde tuz birikimlerinin veya tuz beneklerinin ortaya çıkmasına neden olmaktadır (Yenmez, 2005).

\section{Araştırma alanın toprak özellikleri ve drenaj durumu}

Ova topraklarının genel özelliklerine bakıldı̆̆ında; ova topraklarının kökenini alüviyal ve yerinde oluşmuş (resüdial) kahverengi ve kırmızımsı kahverengi topraklardan oluşturmaktadır (Öztürkmen ve Yavaş, 2014).

Bölgede yer yer tuzluluk sorunu görülmektedir. Harran Ovasında mevcut koşullarda drenaj, doğal drenaj dereleri ile sağlanmaktadır. Harran Ovasının ortasından kuzey-güney yönünde Cullap Deresi uzanmaktadır. Bu dere aynı zamanda Devlet Su İşleri tarafından ovanın drenajını sağlayan ana tahliye kanalına dönüștürülmüștür. Cullap Deresi dıșında Fatik Dağları yönünde gelen Cudi Deresi ve Tektek Dağları eteklerinden gelen Arıcan Deresi Akçakale doğusunda Cullap Deresine karışmaktadırlar. Cullap Deresi ise ovanın sulanmasında kullanılan fazla suların aktarıldığı ana tahliye kanalı olması nedeniyle sürekli akış gösterir. Cullap Deresi sığ ve fazla geniş olmayan bir yatağa sahip olması nedeniyle drenajın sağlanmasında yetersiz kalmaktadır (Yenmez, 2005).

\section{Yöntem}

Araștırma alanındaki arazilerin sulanmasında kullanılan 3 adet regülatörden ve sınır dışına giden Arıcan Ana Tahliyesinden tuzluluk değerlerinin yıl boyunca izlenilmesi amacı ile 12 ay boyunca örnek alınmış, sulama suyu sınıfını belirlemek için ise Haziran ayında bir örnekleme yapılmıştır. Su örnekleri Sağlam (1978)'in belirttiği șekilde alınmıștır. Alınan örnekler laboratuvar ortamına getirilip, burada gerektiği gibi muhafaza edilerek pH, Elektriksel İletkenlik (EC) analizi, $\mathrm{Na}$, Ca ve Mg iyonları için analizler yapılmıştır.

Su Örneklerinde; pH ve EC Richards (1954)'e göre; çözünebilir $\mathrm{Ca}^{+2}$ ve $\mathrm{Mg}^{+2}$, EDTA ile titrasyon metodu ile Sodyum belirlenmesi ise Fleymfotometre kullanılarak yapılmıştır.

\section{Araştırma Bulguları ve Tartışma}

Regülatör ve tahliye suyunun kriterleri ve değerlendirilmesi

Sulama suyu kalitesinin değerlendirilmesinde kullanılan 4 önemli başlık bulunmaktadır. Bunlar; eriyebi- lir tuzların toplam konsantrasyonu, sodyum iyonunun nispi oranı, özel iyon toksiteleri ve diğer kriterler olarak sınıflandırılmaktadır.

Sulama suyu tuzluluğu toprak çözeltisi konsantrasyonunu önemli şekilde etkiler ve artmasına neden olur. $\mathrm{Bu}$ nedenle sulama suyunda tuz miktarı ne kadar yüksekse toprak çözeltisinde tuz konsantrasyonuda o kadar fazladır.

Çizelge 1. Araștırma alanında bulunan regülatör ve tahliye kanalına ait analiz sonuçları

\begin{tabular}{ccccc}
\hline & Turluk & Küplüce & Yardımlı & Arıcan \\
\hline $\mathrm{pH}$ & 7.28 & 7.36 & 7.64 & 7.80 \\
$\mathrm{EC}(\mathrm{dS} / \mathrm{m})$ & 0,76 & 1,30 & 0,73 & 1,17 \\
$\mathrm{Na}(\mathrm{mg} / \mathrm{L})$ & 39.29 & 99.72 & 40.60 & 94.68 \\
$\mathrm{Ca}(\mathrm{mg} / \mathrm{L})$ & 74.12 & 123.39 & 75.58 & 106.16 \\
$\mathrm{Mg}(\mathrm{mg} / \mathrm{L})$ & 18.74 & 40.82 & 21.86 & 35.43 \\
$\mathrm{SAR}$ & 5.77 & 11.00 & 5.82 & 11.25 \\
Sinıfi & $\mathrm{C} 3 \mathrm{~S} 1$ & $\mathrm{C} 3 \mathrm{~S} 2$ & $\mathrm{C} 2 \mathrm{~S} 1$ & $\mathrm{C} 3 \mathrm{~S} 2$ \\
\hline
\end{tabular}

Sulama suyunda $0.7 \mathrm{dS} / \mathrm{m}$ ye kadar kullanım kısıtlaması yapılmamakta olup, 0.7-3.0 dS/m arası kullanımlarda dikkatli olunması, $3.0 \mathrm{dS} / \mathrm{m}$ den yüksek değere sahip sulama suyunun kullanılması uygun değildir (SKKY, 1991).

Sulama suyu kalitesinde diğer önemli olan kriter ise Sodyum iyonunun nispi (SAR) oranıdır. Aşırı $\mathrm{Na}^{+}$ içerek sulama sularının toprağın fiziksel özelliklerinde olumsuz özellikleri vardır. SAR oranı değerlendirilirken EC değeri ile birlikte değerlendirilmelidir. Sulama suyunda SAR oranının \%20-40, EC değerinin $2.9 \mathrm{dS} / \mathrm{m}$ den fazla olduğu durumlarda bu sulama suyunun sulamalarda kullanılmaması gerekmektedir (SKKY, 1991). Ovada sulama ve takviye amaçlı olarak tahliye suları geri dönüştürülerek kullanılmakta olup, bu noktalarda geri dönüşüm bazı bölgelerde pompalar vasıtası ile bazı bölgelerde cazibe ile sağlanmaktadır. Bu dönüşümün \%80'i cazibe ile \%20'si ise pompalar vasitası ile sağlanmakta olup, tahliyeye aktarılan suyun yaklaşık \%25'i sulamaya tekrar verilerek değerlendirilmektedir (DSİ, 2014). Bunun yanı sıra ovada araştırma sürecinde yapılan incelemelerde birliklerce tesis kurularak tahliye suyunun yedek sulama kanallarına aktarıldığı görülmektedir.

Söz konusu alanda bulunun 3 regülatör (Turluk, Yardımlı ve Küplüce) ile Tahliye Kanalının (Arıcan) sulama suyu kriterinde değerlendirilmesinde kullanılacak haziran ayına ait değerler (Çizelge 4.1.)'de verilmiştir. Yukarıdaki çizelgede görüldüğü üzere $\mathrm{pH}$ değerleri; 7.28 ile 7.80 arasında değişmekte olup, tüm örneklerin $\mathrm{pH}$ değerleri sulamada kullanılabilir sinıftadır. 
Elektriksel iletkenlik değerlerine bakıldığında, tüm su örnekleri 3. sınıfta $(0.75-2 \mathrm{dS} / \mathrm{m})$ yani kontrollü kullanılabilir durumdadır. $\mathrm{Na}, \mathrm{Ca}$ ve $\mathrm{Mg}$ miktarları SAR oranı hesaplamasında kullanılmış olup, su örneklerine ait SAR oranları incelendiğinde, Turluk ve Yardımlı Regülatörünün SAR oranı açısında 1. sınıf (<10), Küplüce Regülatörü ve Arıcan Ana Tahliyesinin 2. sınıf (10-18) olduğu ve kontrollü kullanılabilir seviyededir. Yukarıda verilen çizelgeye göre analiz sonuçları örnek noktaları kapsamında değerlendirildiğinde suların pH değerlendirmesi Şekil 2'dedir.

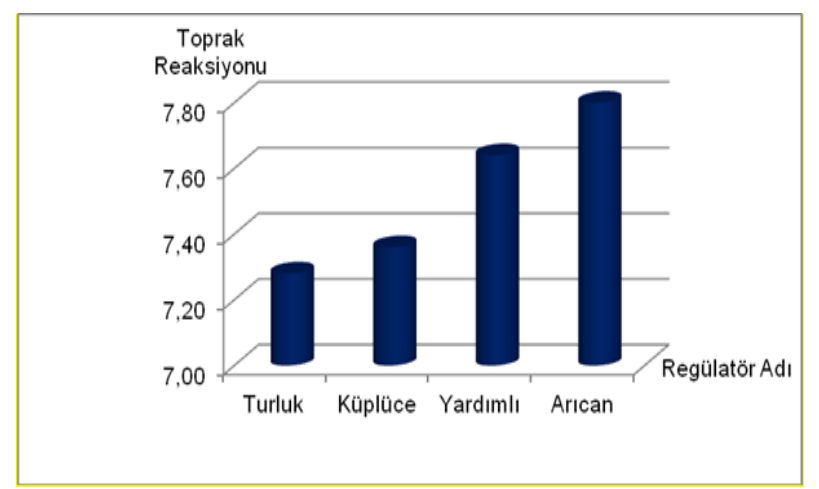

Şekil 2. Su örneklerine ait pH değerleri

Şekil 2'de yer alan sulama suyuna ait pH değerinin en yüksek Arıcan Ana Tahliyesinde olduğu en düşük ise Turluk Regülatöründe olduğu görülmektedir. Örnek noktaları arasında büyük bir farklılık gözlemlenmemiștir. Farklı regülatörleden alınan suların EC değerleri karşılaştırılması (Şekil 4.3.)'te görülmektedir.

Şekil 3'te yer alan elektriksel iletkenlik değerlerine bakıldığında, tuzluluğun en fazla Küplüce Regülatöründe olduğu en düşük ise Yardımlı Regülatöründe olduğu görülmektedir. Sulama sınıflarında elektriksel iletkenliğe göre tuzluluk sınıflandırmasına göre $0.75-2 \mathrm{dS} / \mathrm{m}$ arasındaki değerler tuzlu, 2-3 dS/m üzeri ise çok yüksek tuzlu su sınıfına girmektedir. $\mathrm{Bu}$ nedenle tüm su örneklerinin sulamada kontrollü kullanılmasında yarar bulunmaktadır. Farklı regülatörlerden alınan suların SAR değerleri Şekil 4'te grafiklenmiştir.

Şekil 4'te yer alan su örneklerinde hesaplanan SAR oranında ise en yüksek SAR oranı yine Küplüce Regülatörü ve Arıcan Ana Tahliyesinde olup, en düşük ise Turluk Regülatöründedir. Küplüce Regülatörü ve Arıcan Ana Tahliyesi Orta Sodyumlu Su sinıfinda olup, yüksek değerler çevrede tuzlu alandan yıkanan katyonların karışması ile ilgilidir.

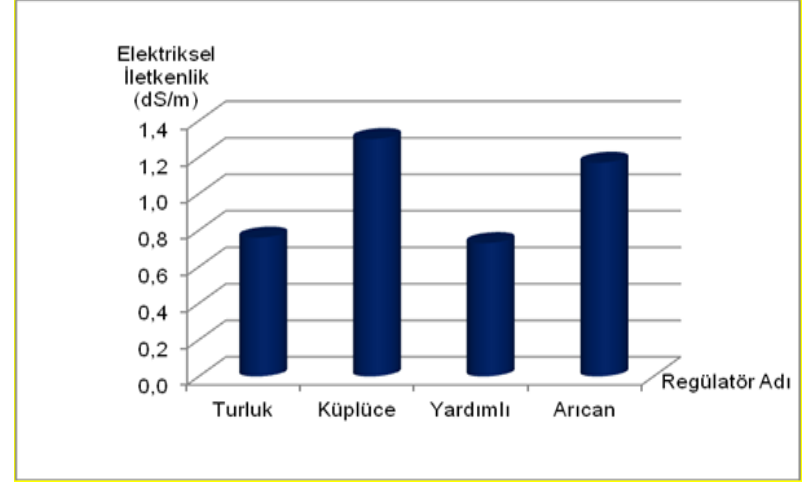

Şekil 3. Su örneklerinin elektriksel iletkenlik değerleri

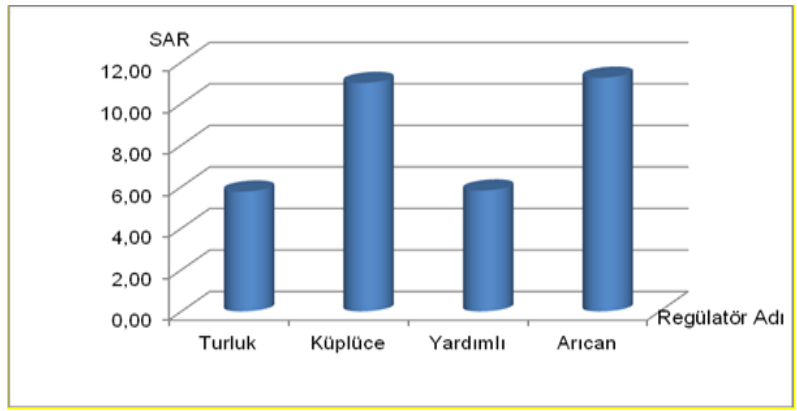

Şekil 4: Su örneklerinin SAR değerleri

Yukarıda verilen sinıflandırmalara göre Turluk Regülatöründen alınan su örneğinde (C3S1) yüksek tuzlu-düşük sodyumlu değerlere sahiptir. Bu nedenle kullanımında tuz içeriği nedeniyle tarımda seyreltilerek kullanılacağı alanlarda mutlaka drenaj sistemi olmalı ve topraktaki tuzluluk değişimi izlenmelidir.

Küplüce regülatörü ve Arıcan Tahliye Kanalından alınan su örneğinde (C3S2) yüksek tuzlu-orta sodyumlu olduğu belirlenmiştir. Arıcan Ana Tahliye Kanalı ve Küplüce Regülatörünün tuz içeriğinin yüksek olmasının sebebinin sulamadan dönen suların yoğun olarak Küplüce Regülatörü ve Arıcan Ana Tahliyesine aktarılmaktadır. Na içeriği yüksek olan bu suların sulamada seyrelme yapılarak kontrollü kullanılması ve sulanan alanlardaki toprak tuzluluğunun izlenmesinde yarar bulunmaktadır.

Yardımlı regülatöründen alınan su örneğinde (C2S1) orta tuzlu-düşük sodyumlu olduğu belirlenmiştir. Tuzluluk ve $\mathrm{Na}^{+}$seviyesi kritik sinırlarda olup sulamada kontrollü kullanılmasında yarar bulunmaktadır. Araştırma alanında bulunan Turluk, Küplüce, Yardımlı Regülatörü ve Arıcan Ana Tahliyesinde 2015 yllı boyunca alınan su örneklerinin elektriksel iletkenlik değerleri (Çizelge 4.2.)'de verilmiştir. 
Çizelge 2. Regülatörlerden alınan su örneklerinin aylık ortalama EC değerleri (2015)

\begin{tabular}{cccccccccccccc}
\hline & Ocak & Şubat & Mart & Nisan & Mayıs & Haziran & Temmuz & Ağustos & Eylül & Ekim & Kasım & Aralık \\
\hline $\begin{array}{c}\text { Arıcan EC } \\
\text { değeri (dS/m) }\end{array}$ & 6.1 & 6.8 & 6.8 & 5.6 & 4.8 & 1.2 & 2.0 & 1.5 & 0.9 & 4.3 & 7.8 & 7.2 & 0.7 \\
\hline $\begin{array}{c}\text { Küplüce EC } \\
\text { değeri (dS/m) }\end{array}$ & 4.1 & 0.8 & 2.1 & 0.7 & 0.9 & 1.3 & 0.7 & 1.8 & 0.7 & 0.9 & 1.0 & 1.0 \\
\hline $\begin{array}{c}\text { Yardımlı EC } \\
\text { değeri (dS/m) }\end{array}$ & 1.3 & 1.2 & 0.8 & 0.7 & 0.9 & 0.5 & 0.5 & 0.5 & 0.5 & 1.2 & 0.8 & 1.0 \\
\hline $\begin{array}{c}\text { Turluk EC } \\
\text { değeri (dS/m) }\end{array}$ & 0.6 & 0.7 & 0.7 & 0.6 & 0.7 & 0.6 & 0.5 & 0.5 & 0.5 & 0.7 & 0.7 & 0.6 \\
\hline
\end{tabular}

Çizelge 2'de görüldüğü üzere Arıcan Ana tahliyesinin en düşük EC değeri $0.9 \mathrm{dS} / \mathrm{m}$ ile Eylül ayında, en yüksek değeri ise $7.8 \mathrm{dS} / \mathrm{m}$ ile Kasım ayında görülmüştür. Arıcan Ana Tahliyesinin Haziran-Eylül arasında kalan aylar dışında ki aylarda sulamada kullanılması uygun değildir. Küplüce Regülatörünün ise en düşük EC değeri $0.7 \mathrm{dS} / \mathrm{m}$ ile Nisan, Temmuz ve Eylül aylarında, en yüksek değeri ise $4.1-\mathrm{dS} / \mathrm{m}$ ile Ocak ayında görülmüştür. Küplüce Ocak ayı dışında sulamada kullanılmasında bir sakınca bulunmamaktadir.

Yardımlı Regülatörüne ait en düşük EC değeri 0.5 $\mathrm{dS} / \mathrm{m}$ ile Ağustos ayında, en yüksek değeri ise 1.3 dS/m ile Ocak ayında görülmüştür. Turluk Regülatörünün ise en düşük EC değeri $0.5 \mathrm{dS} / \mathrm{m}$ ile Ağustos ayında, en yüksek değeri ise $0.7 \mathrm{dS} / \mathrm{m}$ ile Mart ayında görülmüştür. Yardımlı ve Turluk Regülatörlerinin tuzluluk seviyeleri yıl boyunca kullanılabilir durumdadır. Araştırmamızda kullanılan 3 adet regülatöre ve 1 adet ana tahliyeye ait aylık EC (dS/m) değerleri verilmiş olup, en yüksek değerlerin Arıcan Ana Tahliyesinde olduğu görülmektedir.

Grafikte ve tabloda yer alan sulama alanlarından dönen tahliye sularının yıllık EC değişimleri incelenecek olursa, tüm örneklerde Mayıs ayı ile başlayan bir düşüş görülmekte olup bu düşüşün sebebinin bu dönemde sulamanın yoğun olması nedeniyle, kanal, kanalet vb. sanat yapılarının kapasitesinden fazla su yüklenmesi ve hat sonlarında oluşan müdahaleler nedeniyle tahliyelere yüksek miktarda temiz suyun karışması olduğu düşünülmektedir. Bu nedenle Atatürk Barajı'ndan ovaya bırakılan EC değerleri 0.3-0.4 $\mathrm{dS} / \mathrm{m}$ olan su ile seyrelme olmaktadır. Sulama sonrası dönemde (Ekim-Mayıs) ayları arası drenaj suları temiz sulama suyundan etkilenmediğinden bu dönemde genelde elektriksel iletkenlik değeri en yüksek değerlere ulaşmaktadır.

\section{Sonuçlar ve Öneriler}

Araştırma kapsamında bulunan 4 önemli regülatörden alınan su örneklerinin elektriksel iletkenlikleri- nin yll boyunca izlenmesi sonucunda Turluk ve Yardımlı Regülatörleri sularının tuzluluk değerleri Küplüce ve Arıcan regülatörlerine göre daha düşük çıkmaktadır. Örnek alınan bu regülatörlerin etki alanında geri dönüşüm veya pompaj uygulaması ile sular alınarak sulamada kullanılmaktadır. Yıl içerisinde değişim gösteren bu sular, tuz içeriklerine bağlı olarak topraklara tuz eklenmesine katkıda bulunmaktadir.

Küplüce Regülatörü ve Arıcan Ana Tahliyesi orta sodyumlu su sınıfında olup kullanılması kontrollü bir şekilde ve daha kaliteli sularla seyreltme yapılarak kullanılmalıdır. Sodyum içeriği yüksek olan bu sularla sulanan alanlardaki toprakların tuzlulukla ilgili parametreleri yıllık olarak izlenmelidir. Bu alanlarda taban suyunun yüksek olması, verilen su miktarını da ürün desenine göre planlaması yapılmalıdır.

DSİ 15. Bölge Müdürlügü'nün bölgede geri dönüşüm sularını yeniden sulamada kullanmasında $1 / 3$ oranında temiz su/tahliye suyu uygulayarak kullanılmaktadır. Bu deneyimler, toprak özellikleri, ürün deseni ve suların tuz içeriğine göre bir karışım yapılarak sulamada kullanılabilir.

Araştırma alanında yapılan örneklemeler ve analiz sonuçlarına göre toprak reaksiyonu, EC, organik madde, bünye ve kireç özellikleri incelendiğine, toprakların killi, yüksek kireçli olduğu, tuz içeriklerini de uluslararası standartlara göre $2-4 \mathrm{dS} / \mathrm{m}$ değerleri arasında (Richards, 1954) olduğu dikkati çekmektedir. $\mathrm{Bu}$ tahliye suları ile sulanan topraklardaki tuz birikimi taban suyu derinliğinin fazla olması durumunda düşük olmaktadır. Taban suyu yüksek olan alanlarda tahliye suları ile yapılan sular daha sınırlı yapılmalı veya seyreltme faktörü yüksek tutulmalıdir.

Sonuç olarak Şanlıurfa Harran Ovasında yüksek potansiyel taban suyu tehlikesi nedeniyle tuzlanma riski önemli bir konu olmaktadır. Yapılan analiz sonuçlara göre sulama suyu kalitesi düşük olan sulama sularının tarımda kullanılması halinde, suyun kalite 
değerleri izlenmeli, toprak ve bitkiye zarar vermemesi için seyreltme yapılması olumsuz etkilerin önüne geçecektir. Bu nedenle ovada bulunan tahliye suyunun sulamada kullanılmadan önce muhakkak seyreltilmesi ve seyreltme oranı ile su ve topraktaki tuzluluk oranları arasında bir çalıșma yapılarak kontrol altında tutulması gerekmektedir.

Ayrıca GAP, İmambakır ve Reha Sulama birlikleri alanlarında drenaj tedbirlerine yönelik etüt, proje ve inșaat çalıșmalarına hız verilmeli, potansiyel tehlikenin büyük olması nedeniyle bu çalıșmalar ova geneline yayılmalıdır. Ovada geniş ölçüde çiftlik drenajı tesisleriyle ile birlikte açık derin drenaj kanallarına ihtiyaç vardır.

\section{Kaynaklar}

Akış, A., Kaya, B., Seferov, R., Başkan H.O., 2005. Harran Ovası ve Çevresindeki Tarım Arazilerinde Tuzluluk Problemi ve Bu Problemin İklim Özellikleriyle İlişkisi. Selçuk Üniversitesi Sosyal Bilimler Enstitüsü Dergisi, 1(14): 21-38.

Alcamo, J., J.M. Moreno, B. Novaky, M. Bindi, R. Corobov, R.N.J. Devoy, C. Giannakopoulos, E. Martin, J.E. Olesen, and A. Shvidenko. 2007. Europe. Climate change 2007: Impacts, adaptation and vulnerability, p. 541-580. In: Parry, M.L., O.F. Canziani, J.P. Palutikof, P.J. van der Linden, and C.E. Hanson (eds.). Contribution of working group II to the Fourth Assessment Report of the Intergovernmental Panel on Climate Change. Cambridge Univ. Press, Cambridge, UK.

Anonim, 2017. TC Orman ve Su İşleri Bakanlığı Meteoroloji Genel Müdürlüğü. İllerimize ait istatistiki veriler. http://www.mgm.gov.tr/veridegerlendirme Erişim tarihi: 20.05.2017

Apan, M., 1992. Bafra ve Çarşamba Ovalarının Sulama ve Drenaj Yönünden Genel Sorunları ve iyileștirme ile ilgili Çalıșmaları. IV. Ulusal Tarımsal Yapılar ve Sulama Kongresi bildirileri.

Așık, Ş., Avcı, M., Balcı, A., 1997. Atık Suların Sulamada Kullanım Stratejileri. 6. Ulusal Kültürteknik Kongresi Bildirileri Kitabı, 5-8 Haziran 1997, Bursa, 564-576s.

Berekatoğlu, K., Bahçeci İ., 2005. Harran Ovasında Drenaj Kanal Sularının Sulamada Kullanılma Olanakları, Harran Üniversitesi Ziraat Fakültesi Dergisi, Şanlıurfa, 9(3):43-52s

Büyükkamacl, N., 2008, "Su Yönetiminin Etkin Bileșeni: Yeniden Kullanım "İzmir Kent Sorunları Sempozyumu, http://www.imoizmir.org.tr /User Files/ File/Izmir-Kent Sempozyumu /bildiriler /200833.pdf (Erişim Tarihi: 2010).
Çiftçi, N., Kara, M., Yılmaz, M., Uğurlu, N., 1995. Konya Ovasında Drenaj Suları İle Sulanan Arazilerde Tuzluluk Ve Sodyumluluk Sorunları. 5. Ulusal Kültürteknik Kongresi Bildirileri, 471-481, Antalya.

Çullu, M. A., Çelik, İ., Almaca, A., 2000. Degradation of The Harran Plain Soils Dueto Irrigation. Proceedigns of International Symposium on Desertification. 13-17 June Konya-Turkey. P-193-197.

Çullu, M. A., Aydemir S., Sahin Y., Karakas S., Aydoğdu M., Altundal M., Aydemir A., Celiker M., Gürses Ü., 2008. Harran Ovası'nda Sürdürülebilir Su ve Tuzlulaşma Yönetimi. Sulama tuzlanma konferansı.

Çullu, M.A. 2010. Harran Ovası Tuzluluk Haritasının Oluşturulması ve Tuzlulașmanın Bitkisel Verim Kayıplarına Etkisinin Tahmini.

Devlet Su İşleri 2015. XV. Bölge Müdürlüğü, İşletme ve Bakım şubesi, Toplu Makine Çalışma Programı.

Dizdar, M.Y., 2003. Türkiye'nin Toprak Kaynakları, TMMOB Teknik Yayınları Dizisi No: 2, Ankara, 273 s.

Doğan, M., 2003. Şanlıurfa'da Karakoyun Deresi Atık Suları ile Sulanan Soğanda (Allium cepa L.) Toksik Element Birikimi Üzerine Bir Araştırma. Ekoloji Çevre Dergisi. 12 (48).

Gökçay, C., 2008. Arıtılmış Atık suların Tarımda Geri Kullanılması. DSİ VI. Bölge Müdürlüğü, V. Dünya Su Forumu için Yapılan Konferans, Çağrılı Bildiri, Adana.

İșcan, S., Tepeli, E., Uyan, A., Yaşar, M., Çavdar, A., 2001. Sulamanın Temel Esasları 1, T.C. Tarım ve Köyişleri Bakanlığı, Adana Zirai Üretim İșletmesi ve Mekanizasyon Eğitim Merkezi Müdürlüğü, Yayın No:2, Adana.

Kızıloğlu, F.M., Turan, M., Șahin, U., Kușlu, Y., Dursun, A., 2008. Effects of untreatedand treated waste water irrigation on some chemical properties of cauliflower (Brassica olerecea L. var. botrytis) andredcabbage (Brassica olerecea L. var. rubra) grown on calcareou soil in Turkey. Agricultural Water Management, 95: 716-724

Öztürkmen, A.R., Yavaş, Y., 2014. "Harran Ovasındaki Bazı Toprak Serilerinin Sulama Sonrası Agregat Stabilitesinin Değişimi." Harran Tarım ve Gıda Bilimleri Dergisi 18(2): 6-12.

Richards, L.A., 1954 Diagnosis and Improvement of Saline and Alkali Soils. USDA. Agric. Handbook, 573s.

Sağlam, T., 1978. Toprak Kimyası, Atatürk Üniversitesi Ziraat Fakültesi Uygulama Teksiri, Erzurum.

SKYY, 1991. SKKY Teknik Usuller Tebliği, 7 Ocak 1991 Sayılı 20748 Sayılı Resmi Gazete. 
Tarboton, K.C.,Wallender W.W., Raghuwanshi N.S., 2004. Farm salinity appraisal with water reuse. South Florida Water Management District, West Palm Beach, FL, 33416, USA; Biological and Agricultural Engineering Department, and Department of Land Air and Water Resources, University of California, Davis, CA 95616. USA.
Yenmez, N., (2005). Ova Topraklarının Tuzlanmasına Yeni bir Örnek: Harran Ovası. Balıkesir Üniversitesi Sosyal Bilimler Dergisi, 8 (14), 199-236.

Yurtseven, E., 1993. Drenaj Sularının Yeniden Kullanılması. Topraksu Dergisi, 1: 12-14.

Weber, B., Avnimelech, Y., Juanico, M., 1996. Salt enrichment of municipal sewage: new prevention approaches in Israel. Environ. Manage. 20, 487-495. 